\title{
周期的な水平外力を受ける水の入った円筒タンクの非線形振動応答 - 定常応答に出現する分数調波振動の不安定領域の発生機構 - \\ NONLINEAR OSCILLATION RESPONSES OF CYLINDRICAL TANK WITH WATER ON SHAKING TABLE
}

皆川洋一*

Youichi MINAKAWA

\begin{abstract}
Some nonlinear vibration responses were observed in cylindrical tank with water on shaking table driven by periodic sinusoidal wave. The linear vibration theories never explain occuring these vibration phenomenon. It is reported that they might be caused by initial imperfection of cylindrical shell. Assuming that these responses were caused by geometrical nonlinearity of the system with elastic container and water, we have been studying these nonlinear responses from both theory and vibration test. Here, we report subharmonic vibration responses that branch out on periodic stationary response of the vibration system. They make instability regions on response curves, where subharmonic vibration responses become significant vibration. We show several mechanisms that generate the instability regions of subharmonic vibration on response curves.
\end{abstract}

Keywords : Vibration of Cylindrical Tank, Out-of-roundness Response of Cylindrical Tank, Subharmonic Oscillation Response of Tank, Instability Regions of Stationary Oscillation

円筒タンクの振動、円筒タンクのオバリング、円筒タンクの分数調波振動応答, 定常応答の不安定領域

\section{1. はじめに}

水の入った円筒タンクを水平振動台に載せる振動実験は，二つの 側面から研究されている。一方は，容器が剛であるとして，主に水 の振動（sloshing 振動）を対象にするもの 1),6), 他方は容器と水の相互 作用のバルジング (bulging) 振動に焦点を合わせたもの ${ }^{3)}$ である。 Clough 等2) は水の入った円筒タンクの水平振動実験を行い，線形振 動からは予想できない円断面が変形 (out-of-roundness) する応答等を 報告し, 線形振動理論に基づいては説明できない振動が出現するこ と, この原因は夕ンクに存在する初期不整であろうと予測した。著 者等は, 水平外力を受ける円筒夕ンクに生起するこれらの応答は容 器と水の幾何学的非線形性に起因する非線形振動であると推察し, 理論5),8) 実験9)-21) の両面から検討してきている。特に，ある外力振動 数の下で, 分数調波振動成分が分岐し, 強烈な非線形振動に成長す る不安定領域が発生すること,この領域の発生に関与する条件等を 報告して来た。また, 嶋本等 ${ }^{17)}$ は, 周方向展開次数 $N=8$ の振動モー ドが円筒シェルの周方向フーリエ級数の展開次数（以後周方向展開 次数と記述する） $N=6$ が生起する不安定領域に影響を及ぼしている ことを指摘した。本論文は, 周方向の振動モードを 17 点において 測定した実験成果を示し，次の 3 点を明らかにする。

1. 円筒タンクに入る水の量を連続的に変化させた振動モデルの非 線形応答曲線を観測し, 発生した分数調波振動の不安定領域, お よびこの振動モデルの固有振動数と振動モードを特定する。

2. 各不安定領域の発生に関与する振動モードを分析する。

3. 分数調波振動が分岐する不安定領域の定性的な発生機構, すなわ
ちこの不安定領域を形成する振動モード，および固有振動数と外 力振動数の関係を明らかにする。

\section{2。供試体と応答測定}

実験に用いた水平振動台（寸法 $200 \mathrm{~mm} \times 200 \mathrm{~mm} ）$ ，及び円筒夕ン ク供試体 ${ }^{12)}, 21$ ，および測定器等のアイソメ図を Fig.1 に示す。図中の 供試体は周方向に 2 列のひずみゲージを貼付したモデルである。

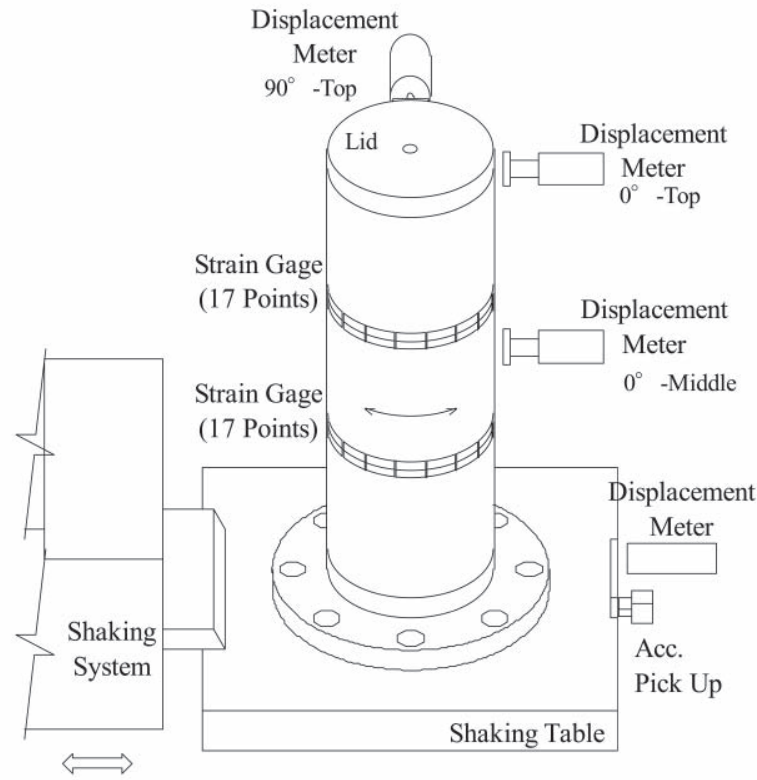

Shaking Direction

Fig.1 Isometric Projection of a Cylindrical Tank on Shaking Table 


\section{1 供試体と周方向の歪測定}

供試体は直径 $84 \mathrm{~mm} ，$ 高さ $200 \mathrm{~mm}$ ，最上部にアクリル製の厚さ $8 \mathrm{~mm}$ のフタをもつ円筒タンクである。フタの中央に直径 $8 \mathrm{~mm}$ の孔があ り，水の出入れに利用された。円筒シェルは厚さ約 $0.51 \mathrm{~mm}$ の塩化 ビニル・フィルムを重ね接合し，造られた。実験の供試体 Mv9，およ び Mv25 ののりしろはそれぞれ $7 \mathrm{~mm}$, 及び $5 \mathrm{~mm}$ とし、ゼリー状のシ アノアクリレート系の接着剂を利用した。Mv9 のみ重㸚接合上の フィルム外面を矢型状に面取りした。この供試体は, 1 周に 17 枚の 歪ゲージ (KLM-6-A9 KYOWA) をタンク底から $85 \mathrm{~mm}$, Mv25 ではタン ク底から $64 \mathrm{~mm}$ ，および $128 \mathrm{~mm}$ の位置 2 周にゲージを貼付した。

近年, 測定装置の $\mathrm{AD}$ 変換時間が早くなり, 高い外力振動数の下 での応答の測定が可能となった。また, 周方向展開次数 $N=8$ の振動 モードが分数調波振動の生起に関与するので, 周方向の 17 箇所のひ ずみ応答を測定し, 円筒タンクの展開次数 $N=0$ から 8 の振動モード を分析した。また，供試体の変位応答は 3 箇所 ${ }^{12)}$ で測定された。

\section{2 データの測定と測定時間差の補正}

測定用の PC に搭載した AD 変換ボード（ADM-681PCI,MICRO SCIENCE） 3 枚を用いて，応答をディジタル量に変換した。

2.2 .1 有限フーリエ級数表示と時間補正

有限フーリエ級数を用いて, 読取りデータを変換するとき, 通常 はサンプリング個数 $M$ を偶数とする。偶数の $M$ を採用し, 外力振動 数 $\omega(\mathrm{rad} / \mathrm{s})$ と, 外力の周期 $T(=2 \pi / \omega)$ の $p$ 倍の時間を $M$ 等分したサンプ リング時間間隔を用いた。このデータは次のように表される。

$$
\begin{aligned}
X_{m} & \simeq \frac{A_{0}}{2}+\sum_{k=1}^{M / 2-1}\left(A_{k} \cos \frac{2 \pi k m}{M}+B_{k} \sin \frac{2 \pi k m}{M}\right) \quad(m=0,1,2, \cdots, M-1) \\
A_{k} & =\frac{2}{M} \sum_{m=0}^{M-1} X_{m} \cos \frac{2 \pi k m}{M}, B_{k}=\frac{2}{M} \sum_{m=1}^{M-1} X_{m} \sin \frac{2 \pi k m}{M}\left(k=0,1,2, \cdots, \frac{M}{2}-1\right)
\end{aligned}
$$

ここに，高次項 $A_{M / 2}$ を無視した。偶数 $M$ が 2 の累乗であると，(2) 式の変換に FFT を利用でき，効率良く $\mathrm{AD}$ 変換が遂行できる。

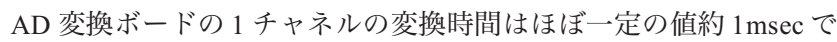
あった。実験での最大サンプリングは 40 点であり，3 枚のボードで $\mathrm{AD}$ 変換すると最大で $14 \mathrm{msec}$ 程度の時間の遅れが生ずる。各測定点 の值を有限フーリエ級数に変換した後，読取り時間の遅れを補正 ${ }^{12)}$ した。この結果, 各測定箇所 $i$ の測定デー夕を統一された時刻 $t$ の 原点を有する次のような連続関数の応答として表すことができる。

$$
X_{i}(t) \simeq \frac{\alpha_{i 0}}{2}+\sum_{k=1}^{M / 2-1}\left(\alpha_{i k} \cos \frac{k \omega t}{p}+\beta_{i k} \sin \frac{k \omega t}{p}\right)
$$

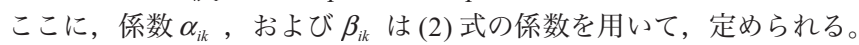
本研究における振動実験では, 測定パラメー夕 $p=6, M=64$ を採用し た。これらのデー夕から，外力振動数と同一の振動数を有する基本 振動成分 $(k=6)$ ，外力の 3 倍の振動数を有する 3 倍高調波振動成分 $(k=18)$ から, 外力の $1 / 3$ 倍の振動数を有する $1 / 3$ 倍分数調波振動成分 $(k=2)$ までの時刻に関する振動成分を分析することが可能となる。

2.3 .2 円筒タンクの振動における周方向モード解析

奇数のサンプリング数 $N c$ を用いたので, 周方向の歪ゲージ 応答に対応する有限フーリ工級数は次式を用いることになる。

$$
X_{\mu}=\frac{\bar{\alpha}_{0}}{2}+\sum_{v=1}^{(N c-1) / 2}\left(\bar{\alpha}_{v} \cos \frac{2 \pi v \mu}{N c}+\bar{\beta}_{v} \sin \frac{2 \pi v \mu}{N c}\right) \quad(\mu=0,1,2, \cdots, N c-1)
$$

$\bar{\alpha}_{v}=\frac{2}{N c} \sum_{\mu=0}^{N c-1} X_{\mu} \cos \frac{2 \pi \nu \mu}{N c}, \bar{\beta}_{v}=\frac{2}{N c} \sum_{\mu=1}^{N c-1} X_{\mu} \sin \frac{2 \pi \nu \mu}{N c}\left(v=0,1, \cdots, \frac{N c-1}{2}\right) \quad(4-\mathrm{a}, \mathrm{b})$

ここに, $N c$ は奇数であり, 本論文では 17 とする。(3) 式を連 続関数表示して，次式を得る。
$X(\theta)=\frac{\bar{\alpha}_{0}}{2}+\sum_{v=1}^{(N c-1) / 2}\left(\bar{\alpha}_{v} \cos v \theta+\bar{\beta}_{v} \sin v \theta\right)$

ここに, $\theta=2 \pi \mu / N_{c}$ 。

今, 周方向の $N c$ 個のデータが時刻応答, および周方向の並びに関し て，それぞれ(3)式, 及び(5)式として表されているとする。このとき， (2)式を(4), および(5)式に代入して, 整理すると次式を得る。

$\varepsilon(\theta, t)=X_{\mu}(t) \simeq \frac{1}{2}\left\{\frac{Q_{00}^{C}}{2}+\sum_{v=1}^{(N c-1) / 2}\left(Q_{v 0}^{C} \cos v \theta+Q_{v 0}^{S} \sin v \theta\right)\right\}$

$+\sum_{k=1}^{M / 2-1}\left[\left\{\frac{Q_{0 k}^{C}}{2}+\sum_{v=1}^{(N c-1) / 2}\left(Q_{v k}^{C} \cos v \theta+Q_{v k}^{S} \sin v \theta\right)\right\} \cos \frac{k \omega t}{p}\right.$

$\left.+\left\{\frac{R_{0 k}^{C}}{2}+\sum_{v=1}^{(N c-1) / 2}\left(R_{v k}^{C} \cos v \theta+R_{v k}^{S} \sin v \theta\right)\right\} \sin \frac{k \omega t}{p}\right] \quad M$ :even, Nc:odd

ここに、 $Q_{v k}^{C}=\frac{2}{N c} \sum_{\mu=0}^{N c-1} \alpha_{\mu k} \cos \frac{2 \pi v \mu}{N c}, Q_{v k}^{S}=\frac{2}{N_{c}} \sum_{\mu=1}^{N c-1} \alpha_{\mu k} \sin \frac{2 \pi v \mu}{N c}$,

$R_{v k}^{C}=\frac{2}{N c} \sum_{\mu=0}^{N c-1} \beta_{\mu k} \cos \frac{2 \pi v \mu}{N c}, R_{v k}^{S}=\frac{2}{N c} \sum_{\mu=1}^{N-1} \beta_{\mu k} \sin \frac{2 \pi v \mu}{N c} ;\left(v=1,2, \cdots, \frac{N-1}{2}\right)$

(6) 式は, 各振動成分 (基本振動成分, 高調波振動成分, 分数調 波振動成分）と周方向 $\theta$ に関する 2 方向の有限フーリエ級数表示 である。本研究において, 各振動成分 $k$ に対する各周方向展開次 数 $v$ の歪応答曲線は, 次式の歪と振動数の関係を用いる。

$\bar{\varepsilon}_{v k}=\sqrt{\left(Q_{v k}^{c}\right)^{2}+\left(Q_{v k}^{s}\right)^{2}+\left(R_{v k}^{c}\right)^{2}+\left(R_{v k}^{s}\right)^{2}} \quad(v=0,1, \cdots, 8 ; k=0,2,3,6,12,18)(8)$

また, (6) 式の歪の 2 乗平均值 $\left(\varepsilon_{r m s}\right)^{2}$ は次のように求められる。

$\left(\varepsilon_{r m s}\right)^{2}=\frac{1}{2 \pi} \frac{\omega}{2 \pi p} \int_{0}^{2 \pi} \int_{0}^{2 \pi p / \omega}\{\varepsilon(\theta, t)\}^{2} d \theta d t=\frac{1}{4}\left\{\frac{1}{4}\left(\bar{\varepsilon}_{00}\right)^{2}+\frac{1}{2} \sum_{v=1}^{(N c-1) / 2}\left(\bar{\varepsilon}_{v 0}\right)^{2}\right.$

$\left.+\frac{1}{2} \sum_{k=1}^{M / 2-1}\left(\bar{\varepsilon}_{0 k}\right)^{2}+\sum_{v=1}^{(N c-1) / 2} \sum_{k=1}^{M / 2-1}\left(\bar{\varepsilon}_{k v}\right)^{2}\right\}$

\section{3. 水の入った円筒タンクの応答}

\section{1 基本振動成分の応答と固有振動数}

3.1.1 基本振動数成分の応答

系の基本的な振動特性を把握するために，水高（50-190mm）をパ ラメータとし, 外力加速度の実効值 $0.5 \mathrm{~g}$ とし, 外力振動数 $\mathrm{Hz}(=$ $\omega / 2 / \pi)$ を 40-720Hz まで変化させて得られる供試体の応答を観測し た。この加速度は水平振動台の加速度であり、単位 $g$ は $9.80665 \mathrm{~m} / \mathrm{s}^{2}$ を表す。供試体 Mv9 の水高 (Water Height, 図中ではWH と表現する) $140 \mathrm{~mm}$ における基本振動成分（外力振動数と同一の振動数を有する 振動成分）の応答を有限フーリ工級数 $(N=0, \cdots, 8)$ に分解して Fig. 2 に 示す。図中に各周方向展開次数を右上に, それに対応するバルジン グ振動の固有振動数の記号（3.1.2 に示す）を付した。

\subsection{2 固有振動数}

系の固有振動数は上述した外力加速度 $0.5 \mathrm{~g}$ の応答のみでは特定し 難いケースがある。ここでは, 有限要素法の解析による固有振動数 ${ }^{21)}$ を参照しながら，固有振動数を特定した。この解析において，円筒 シェル，およびフ夕は 2 節点の円錐台要素，水はポテンシャル流体 と仮定され 3 節点三角形のリング要素にモデル化された。塩化ビニ ル・フィルムのヤング率 $2.8 \mathrm{GPa}$ ，ポアソン比 0.35 を解析に用いた。

供試体 Mv9，および Mv25 の水高 50mm-190mm まで増分 $10 \mathrm{~mm}$ に対 応する各周方向展開次数に対応する最小のバルジング振動の固有振 動数 $\omega_{n 1}(N=0, \cdots, 8)$, 及び 2 番目に小さいバルジング振動の固有振動 数 $\omega_{n 2}(N=1,5,6)$ をそれぞれ Table1, およびTable2 に示す。表中にお いて, 固有振動数 $\omega_{n j}$ を $n . j$ と表記した。固有振動数は実験時の気温, 水温, 外力加速度の大きさ等の影響を受け, 数 $\mathrm{Hz}$ 程度の変動 21$)$ を 示す。巨視的に見ると，接合ののりしろが $5 \mathrm{~mm}$ の供試体 Mv25 はそ れが $7 \mathrm{~mm}$ の供試体 Mv9 より低い固有振動数を有する。一方，Mv25 
は, Mv9 より高次振動モードの固有振動数が若干高くなっている。 これは, Mv25 は周方向に 2 列の歪ゲージを持ち, 母線周りの曲げ 剛性が 1 列のみの Mv9 より高くなつていることの影響と思われる。

\section{2 非線形振動の応答}

3.2.1 正規化された振動モードベクトルの定義

分岐した分数調波振動の振動モードの類似性を判定するために, 次のような振動モードを定義する。外力振動数 $f \mathrm{~Hz}$ における $1 / 2$ 倍

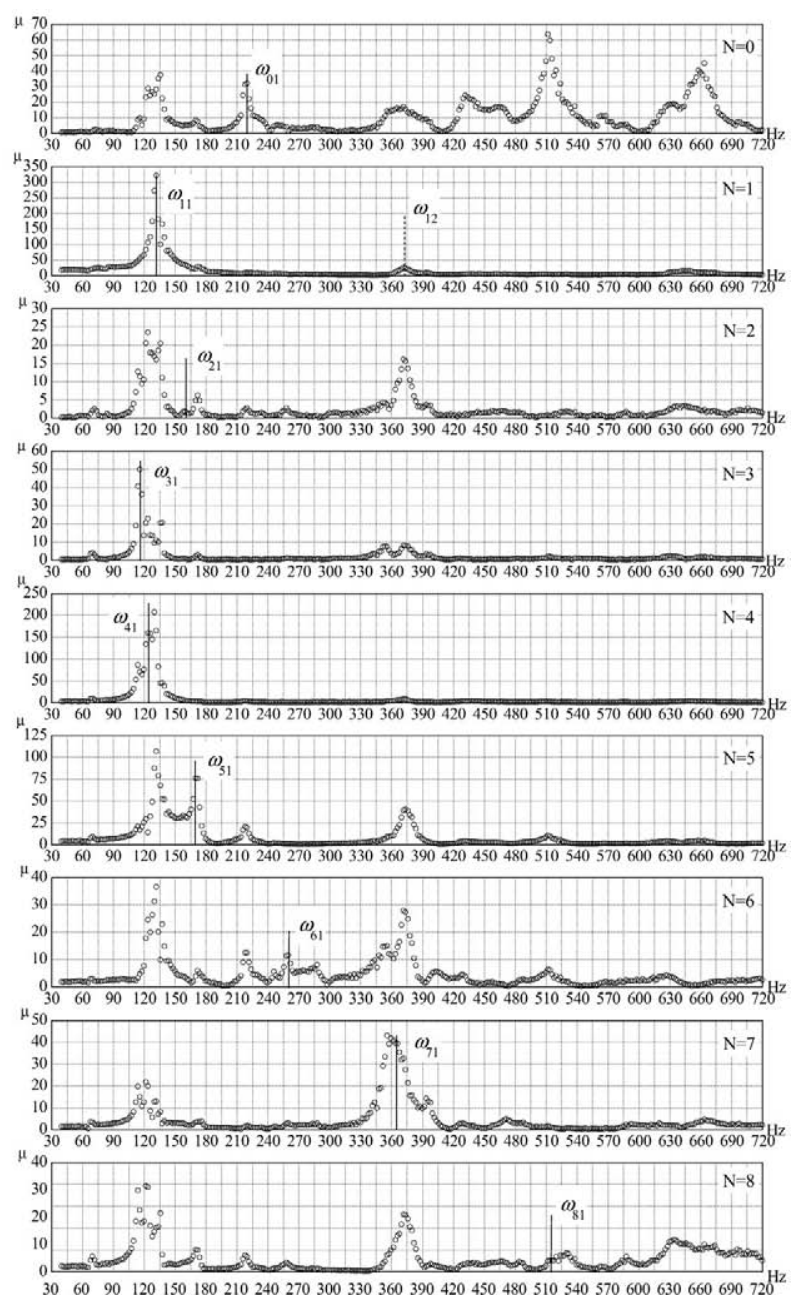

Fig.2 Strain-Frequency Curves for each $\mathrm{N}$ of the Fundamental Oscillation Component (Mv9, $0.5 \mathrm{~g}, \mathrm{WH} 140 \mathrm{~mm}$ )

Table 1. Eigen Frequencies of Specimen Mv9

\begin{tabular}{|c|c|c|c|c|c|c|c|c|c|c|c|c|}
\hline \multirow{2}{*}{$\begin{array}{l}\text { Water } \\
\text { Height } \\
(\mathrm{mm})\end{array}$} & \multicolumn{12}{|c|}{ Vibration Modes \& Eigen Frequencies (Hz) } \\
\hline & 0.1 & 1.1 & 1.2 & 2.1 & 3.1 & 4.1 & 5.1 & 5.2 & 6.1 & 6.2 & 7.1 & 8. \\
\hline 190 & 188 & 88 & & & & 114 & 50 & & $=$ & & 32 & \\
\hline 180 & 18 & 100 & 352 & & 6 & 4 & 44 & 4 & 4 & 272 & 40 & 50 \\
\hline 170 & 190 & 14 & 360 & 44 & 8 & 16 & 58 & 6 & 50 & 27 & 48 & 50 \\
\hline 60 & 10 & 4 & 36 & & & 12 & 164 & & 56 & 28 & 54 & 50 \\
\hline 50 & 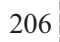 & 124 & 376 & & 112 & 122 & 168 & 205 & 56 & 296 & 58 & 51 \\
\hline 40 & 27 & 132 & 372 & 1 & 116 & 124 & 170 & 218 & 260 & & 56 & 51 \\
\hline 130 & 23 & 140 & 374 & & 122 & 128 & 176 & 232 & 264 & 310 & 366 & 51 \\
\hline 120 & 24 & 150 & 380 & 17 & 128 & 130 & 178 & 244 & 66 & 328 & 364 & 51 \\
\hline 10 & 284 & 158 & 386 & 19 & 136 & 140 & 182 & 284 & 54 & 360 & 360 & 51 \\
\hline 100 & 304 & 164 & 394 & 20 & 146 & 152 & 188 & 300 & 258 & 378 & 360 & 51 \\
\hline 90 & 33 & 170 & 418 & i & 160 & 166 & 196 & 374 & 264 & 410 & 364 & 520 \\
\hline 80 & 34 & 176 & 434 & 25 & 192 & 178 & 210 & 406 & 272 & 440 & 366 & 52 \\
\hline 70 & 38 & 180 & 470 & 282 & 220 & 200 & 230 & 446 & 282 & 514 & 370 & 536 \\
\hline 60 & 43 & 184 & 540 & 322 & 26 & 23 & 256 & 566 & 314 & 568 & 400 & 556 \\
\hline & & 184 & & & 29 & 21 & 302 & & 346 & & 450 & \\
\hline
\end{tabular}

分数調波振動モードの各周方向展開次数 $(N=0, \cdots, 8)$ の歪振幅を成 分とし，ノルムを 1 に正規化したベクトルを $V_{f}^{g W H}$ と表す。例えば, 外力加速度 $2 \mathrm{~g}$, 水高 $100 \mathrm{~mm}$, および $90 \mathrm{~mm}$ に対応するそれぞれの 外力振動数 $f_{1}$, 及び $f_{2}$ における不安定領域において, この正規化さ れた歪振幅ベクトルの内積 $V_{f 1}^{2 g 100} \cdot V_{f 2}^{2 g 90}$ を評価し, 振動モードの類 似性の判断情報とする。

\section{2 .2 高調波振動成分の応答}

円筒タンクに生起する高調波振動応答の例として, 供試体 Mv9, 水高 $140 \mathrm{~mm}$, 外力振動数 $0.5 \mathrm{~g}$ における 2 倍高調波振動成分の応答 を有限フーリ工級数 $(N=0, \cdots, 8)$ に分解して Fig. 3 に示す。図中の周 方向展開次数における最小バルジング振動に対応する固有振動数 の $1 / 2$ 倍の振動数に記号を付した。外力振動数が周方向展開次数 $N=0,1,5,6$ に対応する最小バルジング振動の固有振動数の $1 / 2$ 倍近傍 において, 2 倍高調波振動応答が大きく成長し, 高調波振動応答の 共振が生起する。また, 水平振動の主共振領域（外力振動数 $\omega_{11}$ 近 傍）に抒いて, 基本振動応答（Fig.2）の振幅増加に伴い全ての周方 向展開次数の振動モードに対する 2 倍高調波振動応答が成長する。

\section{2 .3 分数調波振動と不安定領域}

供試体 Mv9, 外力振動数 $1 \mathrm{~g}$, 水高 $140 \mathrm{~mm}$, 外力振動数は $300-600 \mathrm{~Hz}$ における $1 / 2$ 倍分数調波振動成分, および $1 / 3$ 倍分数調波振動成分 の応答を有限フーリ工級数 $(N=0, \cdots, 8)$ に分解し, それぞれ Fig. 4 , お よび Fig.5 に示す。Fig.4 の外力振動数 496-522Hz において, 1/2 倍分 数調波振動応答が分岐する。この応答の主振動モードである周方 向展開次数 $N=6$ の歪振幅は $572 \mu$ を示し, $N=0,5$ に対応する振動モー ドの歪振幅はそれぞれ $210 \mu, 172 \mu$ を示す。この不安定領域は，外 力振動数が周方向展開次数 $N=6$ の最小バルジング振動の固有振動 数 $\omega_{61}$ の 2 倍の振動数 $\mathrm{B}_{61}(=260 \times 2=520 \mathrm{~Hz})$ 近傍に生起する夕イプで あり, ここでは $\mathrm{B}_{61}$ 型の不安定領域と分類する。この不安定領域は 外力加速度が小さいとき, $1 / 2$ 倍分数調波振動応答のみが生起する 不安定領域として発生するが, 応答が大きな振幅に成長すると, $1 / 3$ 倍分数調波振動応答も混在する可能性が高い。外力振動数 500 $502 \mathrm{~Hz}$ において, 周方向展開次数 $N=4$ が主振動モードとなる $1 / 3$ 倍 分数調波振動応答が 2 次分岐 (Fig.5) した。

同一モデルで水高が異なる供試体 Mv9, 外力振動数 $1 \mathrm{~g}$, 水高 $80 \mathrm{~mm}$, 外力振動数は $300-600 \mathrm{~Hz}$ における $1 / 2$ 倍分数調波振動応答を

Table 2. Eigen Frequencies of Specimen Mv25

\begin{tabular}{|c|c|cc:c:c|c:cc:cc:c|c|c|}
\hline $\begin{array}{l}\text { Water } \\
\text { Height }\end{array}$ & \multicolumn{8}{|c|}{ Vibration Modes \& Eigen Frequencies (Hz) } \\
\cline { 2 - 4 } & 0.1 & 1.1 & 1.2 & 2.1 & 3.1 & 4.1 & 5.1 & 5.2 & 6.1 & 6.2 & 7.1 & 8.1 \\
\hline 190 & 188 & 84 & 336 & 150 & 104 & 118 & 172 & 224 & 258 & 282 & 340 & 480 \\
180 & 188 & 98 & 346 & 142 & 102 & 118 & 170 & 224 & 256 & 282 & 358 & 480 \\
170 & 190 & 102 & 360 & 142 & 104 & 120 & 170 & 236 & 254 & 284 & 366 & 488 \\
160 & 200 & 114 & 360 & 146 & 106 & 120 & 174 & 238 & 258 & 294 & 372 & 490 \\
150 & 206 & 122 & 358 & 150 & 110 & 126 & 174 & 242 & 258 & 303 & 370 & 494 \\
140 & 216 & 130 & 360 & 154 & 114 & 124 & 176 & 253 & 262 & 310 & 374 & 498 \\
130 & 226 & 140 & 360 & 160 & 118 & 128 & 178 & 265 & 264 & 310 & 370 & 500 \\
120 & 244 & 148 & 359 & 170 & 126 & 136 & 176 & 286 & 258 & 340 & 374 & 498 \\
110 & 286 & 156 & 362 & 182 & 134 & 142 & 188 & 310 & 258 & 356 & 374 & 502 \\
100 & 304 & 162 & 375 & 194 & 146 & 160 & 196 & 340 & 270 & 374 & 378 & 500 \\
90 & 328 & 170 & 418 & 204 & 158 & 164 & 206 & 380 & 276 & 418 & 374 & 506 \\
80 & 358 & 176 & 448 & 255 & 174 & 180 & 222 & 440 & 288 & 486 & 376 & 510 \\
70 & 384 & 180 & 512 & 280 & 200 & 204 & 236 & 486 & 304 & 522 & 388 & 518 \\
60 & 444 & 182 & 529 & 322 & 230 & 216 & 250 & 490 & 344 & - & 396 & 522 \\
50 & - & 186 & 613 & 352 & - & 278 & 308 & - & 358 & - & 446 & 610 \\
\hline
\end{tabular}


Fig.6 に示す。外力振動数 $350-356 \mathrm{~Hz}$ に周方向展開次数 $N=4$ の歪振幅 が $146 \mu$, それ以外の周方向展開次数の歪振幅が $42 \mu$ 以下となる $\mathrm{B}_{41}$ $(=178 \times 2=356 \mathrm{~Hz})$ 型の不安定領域が出現した。外力振動数 $414-434 \mathrm{~Hz}$ に周方向展開次数 $N=5$ の歪振幅が $365 \mu$, それ以外の展開次数の歪 振幅が $79 \mu$ 以下となる $\mathrm{B}_{51}(=224 \times 2=448 \mathrm{~Hz})$ 型の不安定領域が出現し た。一方, 外力振動数 $486-494 \mathrm{~Hz}$ に周方向展開次数 $N=5$, および 6 の歪振幅がそれぞれ $116 \mu$ ，および $104 \mu ， そ れ ら 以$ 外の展開次数の 歪振幅は $32 \mu$ 以下となる $1 / 2$ 倍分数調波振動応答が分岐した。この 不安定領域は, 外力振動数が周方向展開次数 $N=5$, および 6 に対応 する 2 つ最小バルジング固有振動数の和 $\mathrm{A}_{51,61}(=210+272=482 \mathrm{~Hz})$ 近傍のとき生起する。これを $\mathrm{A}_{51,61}$ 型の不安定領域と分類する。

\section{2 .4 供試体 Mv9（外力加速度 $1 \mathrm{~g}$ ）の不安定領域}

供試体 Mv9, 外力加速度 $1 \mathrm{~g}$, 外力振動数 300-600Hz の下で観測さ れた $1 / 2$ 倍分数調波振動, および $1 / 3$ 倍分数調波振動応答の不安定 領域を Fig.7 に示す。不安定領域のハッチは生起する分数調波振動 と主振動モードの周方向展開次数を表す。 $1 / 2$ 倍分数調波振動のう ち主振動モードの周方向展開次数 $N$ が $4,5,6,0$, 及び 8 に対応して, そ

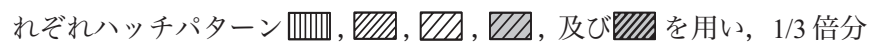
数調波振動のうち主振動モードの周方向展開次数 $N$ が 4,5 , 及び 6 に

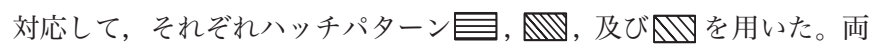
方の分数調波振動が生起した領域は, 2 種類のハッチを重複して図

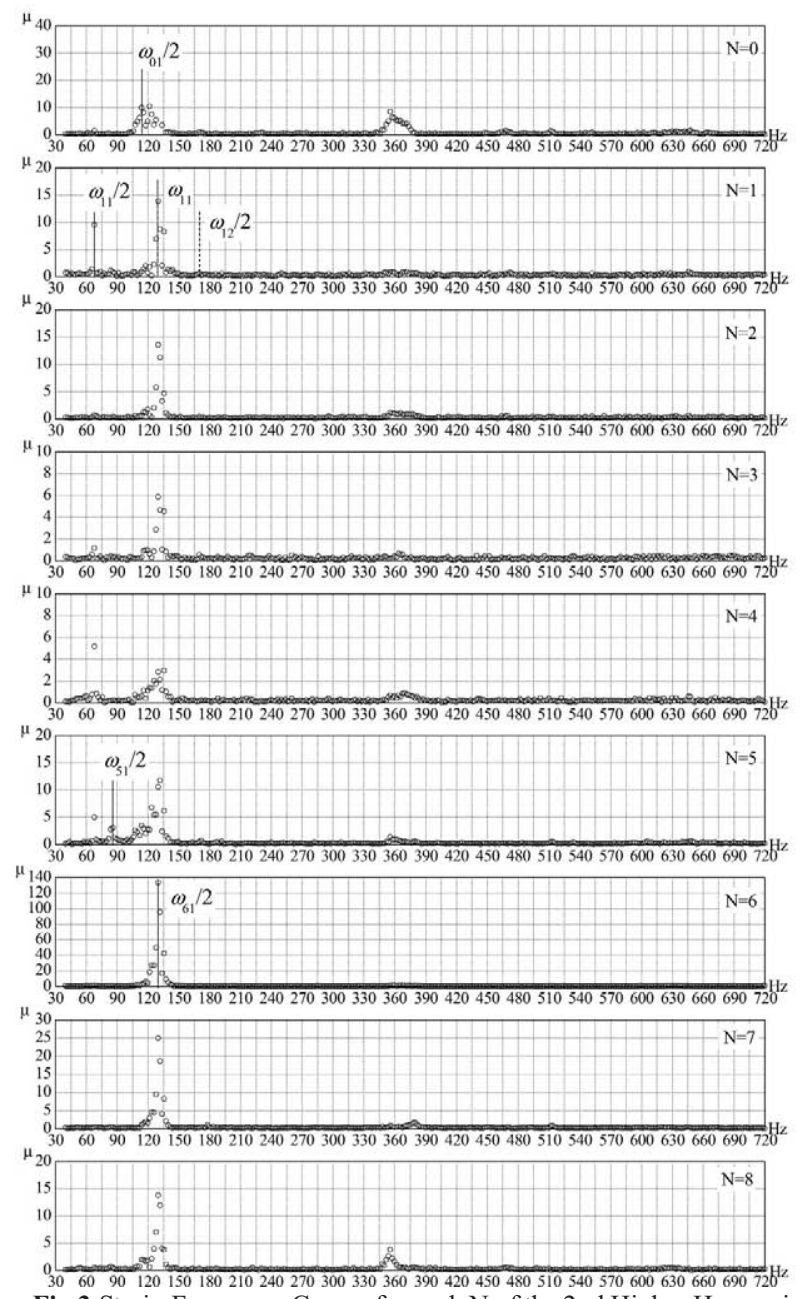

Fig.3 Strain-Frequency Curves for each $\mathrm{N}$ of the 2nd Higher-Harmonic Fundamental Oscillation Component (Mv9,0.5g,WH140mm)
示した。前述した振動数 $A_{41}, A_{51}$, および $A_{61}$ と水高の関係にそれ ぞれ記号曰, , 及び凹を付して Fig.7に示した。外力振動数がこ れらの振動数の近傍にあるとき, 多くの水高において $1 / 2$ 倍分数調 波振動応答が生起した。 3.2 .3 において, 発生の機構が示されなかっ た不安定領域は 4 節，および 5 節において補足説明する。

\section{4 分数調波振動の不安定領域の発生機構}

非線形振動応答の定常的な応答曲線上に, ある条件の下で不安定 状態が発生し, 分数調波振動成分の応答が分岐する。一連の分岐応答 が発生する領域は定常解の不安定領域を形成する。この代表的な発生 機構を前節において例示した。それらの不安定領域の発生機構を類型 化する。また, 不安定領域において, さらに別な分数調波振動の不安 定領域（高次不安定領域）が発生したと推察される応答を示す。

この目的に必要ないくつかの振動数を定義する。振動数 $\mathrm{B}_{n j}, \mathrm{~T}_{n j}$ は系の固有振動数 $\omega_{n j}(n, j$ は自然数) の 2 倍, および 3 倍の值とする。

$\mathrm{B}_{n j}=2 \times \omega_{n j}, \mathrm{~T}_{n j}=3 \times \omega_{n j}$

振動数 $\mathrm{A}_{n j, m k}$ は系の二つの固有振動数 $\omega_{n j}$, および $\omega_{m k}$ の和とする。

$$
\mathrm{A}_{n j, m k}=\omega_{n j}+\omega_{n k}
$$

振動数 $\mathrm{S}_{n j, m k}$ は系の二つの固有振動数 $\omega_{n j}$, および $\omega_{m k}$ 差とする。

$\mathrm{S}_{n j, m k}=\omega_{n j}-\omega_{n k}>0$

(1) 固有振動数の 2 倍近傍の不安定領域

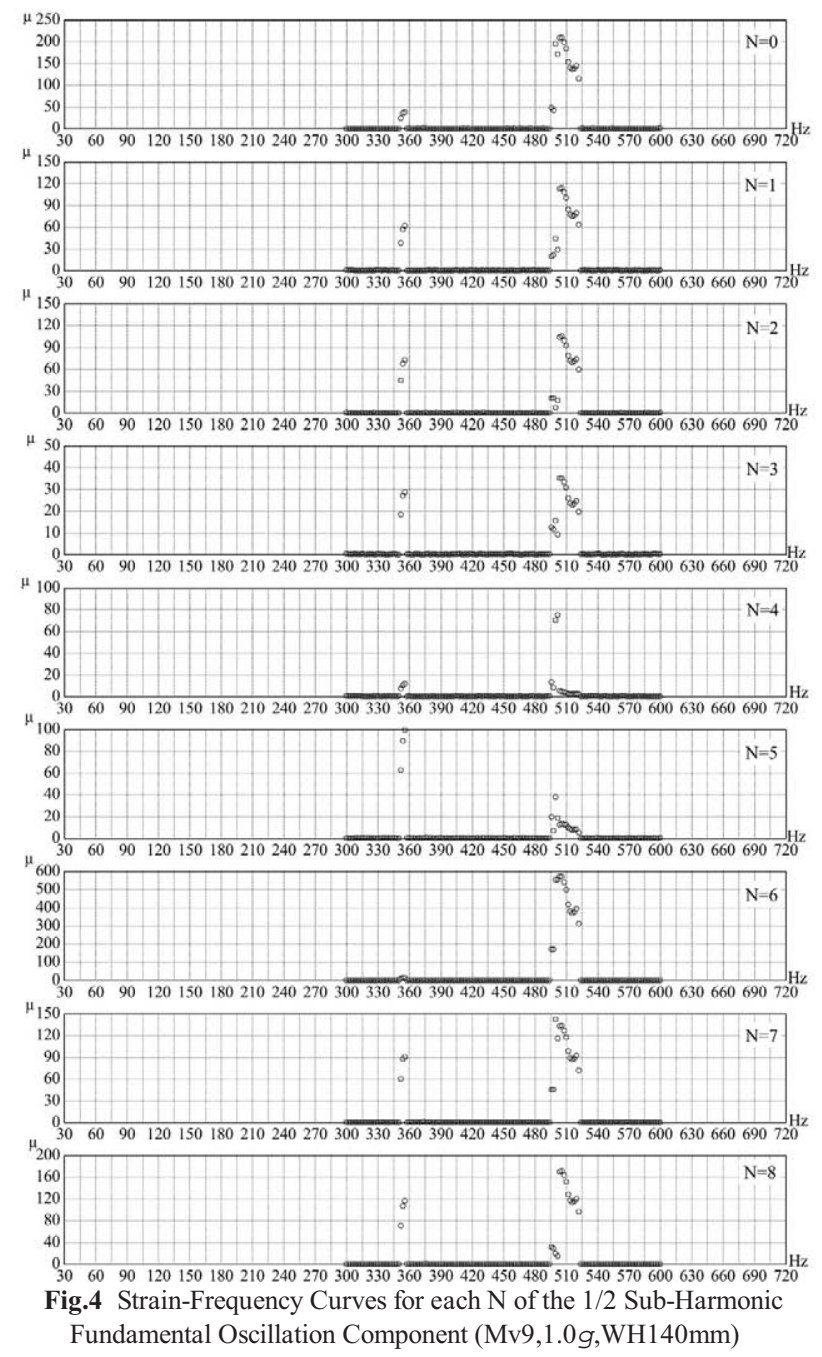


外力振動数が振動数 $\mathrm{B}_{n j}$ 近傍において, この固有振動数に対応す る振動モードを主な振動モードとする $1 / 2$ 倍分数調波振動応答が生 起する。この不安定領域の発生機構を $\mathrm{B}_{n j}$ 型と表す。 $1 / 2$ 倍分数調波 振動応答が生起する時, $3 / 2$ 倍分数調波振動応答も付随して生起す る。1/2 倍分数調波振動応答が生起しても, その振幅が小さいとき, $1 / 3$ 倍分数調波振動応答は生起しない。これを 3.2 .3 に例示した。

(2) 二つの固有振動数の和近傍の不安定領域

外力振動数が二つの固有振動数 $\omega_{51}$, および $\omega_{61}$ の和となる振動 数 $\mathrm{A}_{51,61}$ 近傍において, これらに対応する二つの振動モードを主 要な振動モードとする $1 / 2$ 倍分数調波振動応答が生起する。この 不安定領域の発生機構を $\mathrm{A}_{51,61}$ 型と表す。この型の不安定領域に おいて, $1 / 3$ 倍分数調波振動応答が同時に生起する可能性が高い。 (3) 二つの固有振動数の差近傍の不安定領域

外力振動数が二つの固有振動数 $\omega_{81}$, および $\omega_{21}$ の差となる振動数 $\mathrm{S}_{81,21}$ 近傍において, これらに対応する二つ振動モードが比較的大きな 振動モードと成る $1 / 2$ 倍分数調波振動応答が生起する。

供試体 $\mathrm{Mv} 9$, 外力振動数 $1 \mathrm{~g}$, 水高 $140 \mathrm{~mm}$, 外力振動数 $352-356 \mathrm{~Hz}$ (Fig.4) において, 周方向展開次数 $N=8,5,7,2$ 等の歪振幅がそれぞれ $116 \mu, 99 \mu, 90 \mu, 73 \mu$ の大きな振幅を示す $1 / 2$ 倍分数調波振動応答が分岐す る。この不安定領域の振動数は $\mathrm{B}_{51}(=340 \mathrm{~Hz})$, 固有振動数 $\omega_{71}(=356 \mathrm{~Hz})$ の 近傍にある。この不安定領域はこれらの要因の他, 固有振動数 $\omega_{81}$ と

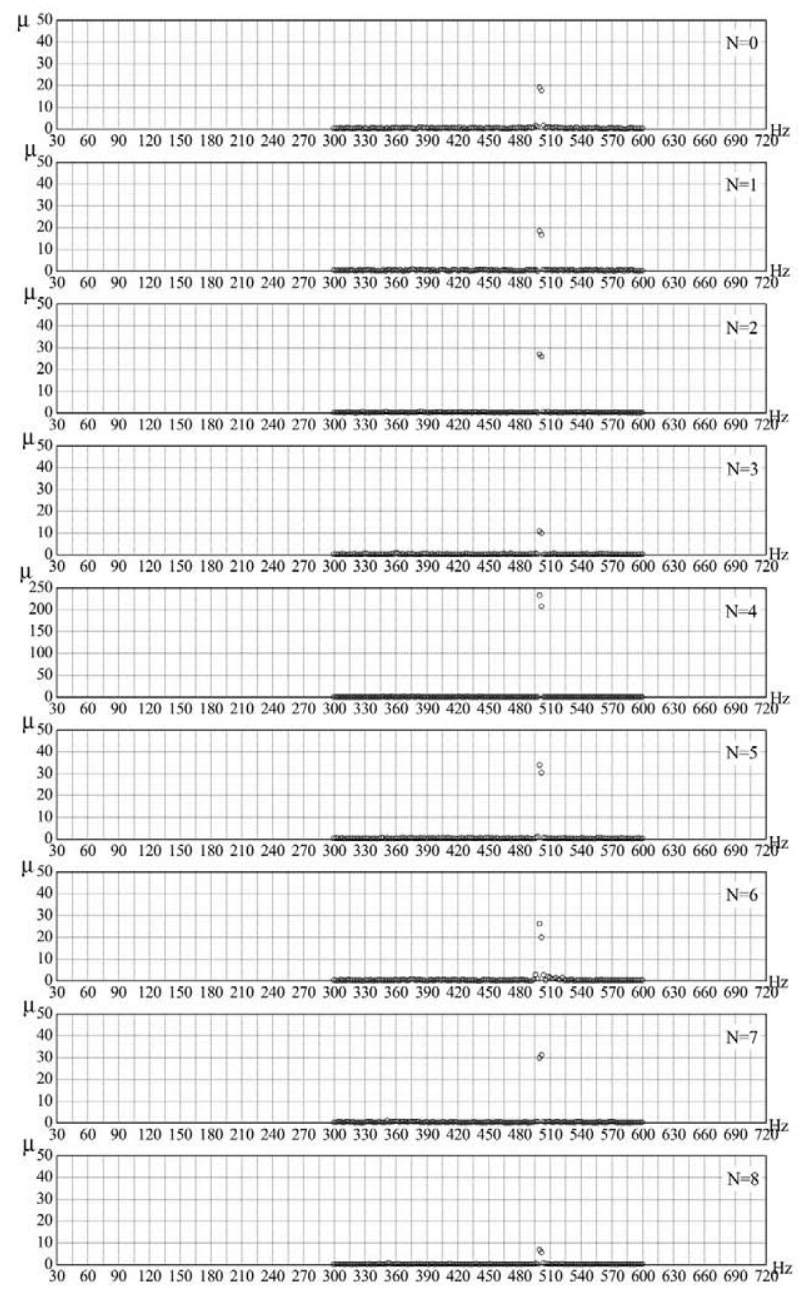

Fig.5 Strain-Frequency Curves for each $\mathrm{N}$ of the $1 / 3$ Sub-Harmonic Fundamental Oscillation Component (Mv9,1.0g,WH140mm) $\omega_{21}$ との差振動数 $\mathrm{S}_{81,21}(=514-160=354 \mathrm{~Hz})$ が関与する不安定領域であ ると判断した。固有振動数 $\omega_{81}$ は $514 \mathrm{~Hz}$ であり, $N=8$ の振動モードは この不安定領域の振動数では通常大きな振幅を示さない筈なのに, この振動モードが最大の歪振幅を示したからである。この不安定領 域の発生機構を $\mathrm{S}_{81,21}$ 型と表す。この判断の補足デー夕を示す。この不 安定領域の外力振動数 $356 \mathrm{~Hz}$ における振動モードと不安定領域 $\mathrm{B}_{51}$ 型 にある水高 $120 \mathrm{~mm}, 90 \mathrm{~mm}, 130 \mathrm{~mm}$, 及び $150 \mathrm{~mm}$ の各不安定領域における

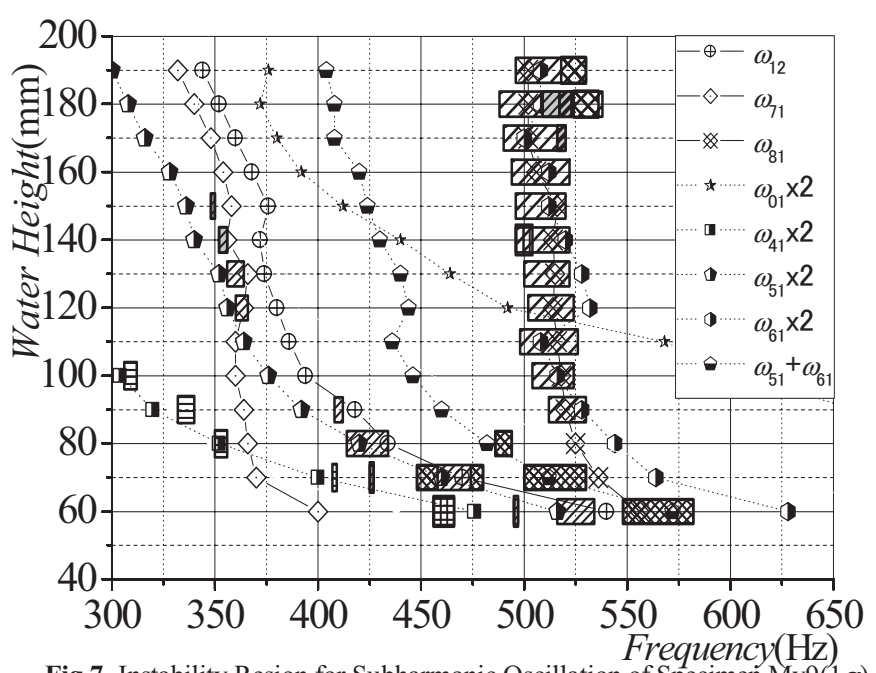

Fig.7 Instability Resion for Subharmonic Oscillation of Specimen Mv9(1g)

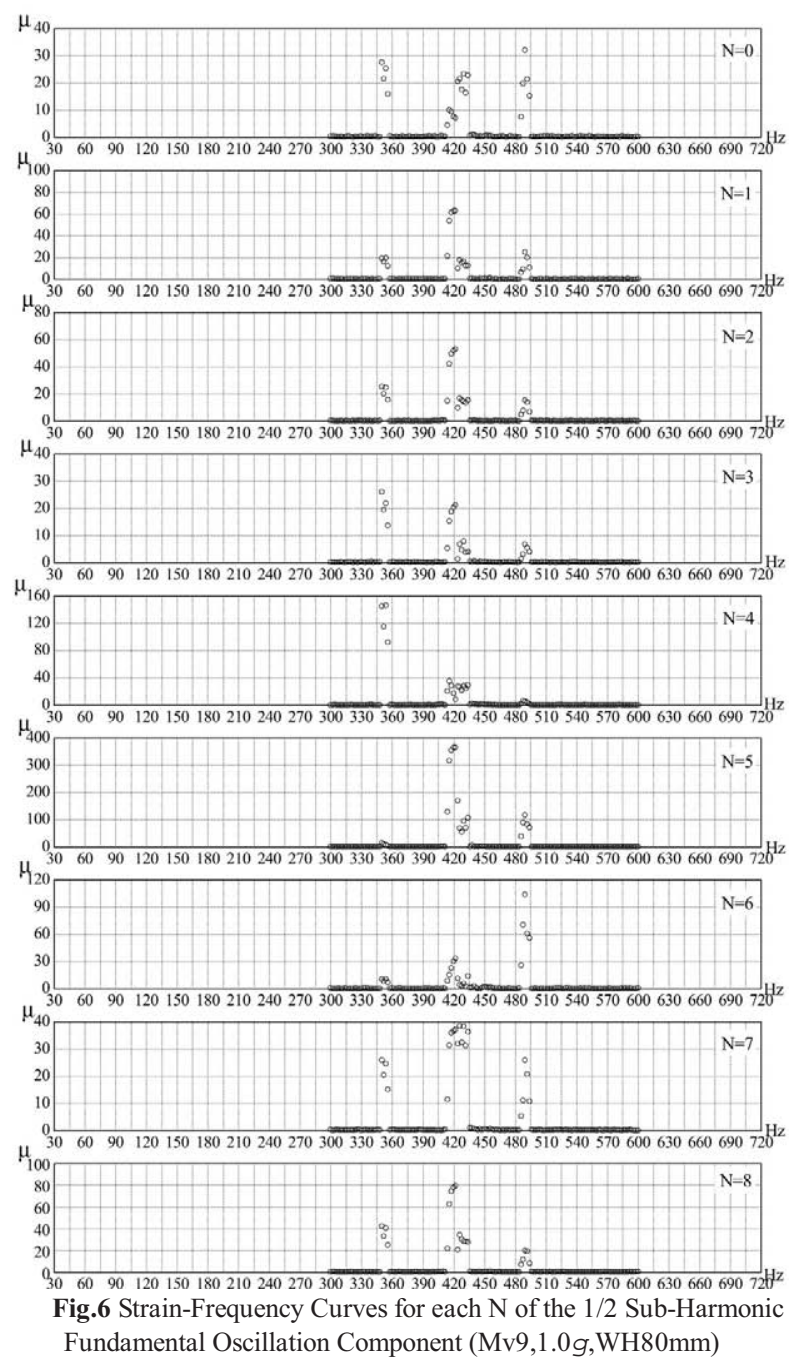


$1 / 2$ 倍分数調波振動応答が最大の振幅となる外力振動数における振動 モードベクトル (3.2.1) を Fig. 8 に示す。水高 $90 \mathrm{~mm}, 120 \mathrm{~mm}, 130 \mathrm{~mm}$ と水 高 $140 \mathrm{~mm}, 150 \mathrm{~mm}$ の振動モードに大きな差異が認められる。前者の 3 ケースの応答は周方向展開次数 $N=5$ が主振動モードである。後者の 2 ケースでは周方向展開次数 $N=8$ が主振動モードであり, $N=7,2$ 等の 振動モードが前者より大きな応答を示す。これら 5 ケースの振動 モードベクトルと $\mathrm{B}_{51}$ 型の水高 $130 \mathrm{~mm}$ のベクトルとの内積(3.2.1) を Table3 に示した。内積は振動モードの相違を数值化した指標と成り得る。

\section{(4) 固有振動数近傍の不安定領域}

主共振領域，すなわち外力振動数が周方向展開次数 $N=1$ の固有振 動数 $\omega_{11}$ 近傍において, 外力加速度が大きくなると, 各周方向展開次 数の歪応答に $1 / 2$ 倍分数調波振動応答が生起する。2 次共振領域を形 成する固有振動数 $\omega_{12}$ に対応する振動モードも大きな外力（加速度） を受ければ，同様な作用を有すると予測される。逆に，大きな外力 を受けなければ，固有振動数近傍の外力振動数の下でも，対応する 振動モードの分数調波振動応答は生起し難いと判断される。

しかし, 上記 $\mathrm{S}_{81,21}$ 型の不安定領域は, 固有振動数 $\omega_{71}$ の近傍にあり, $N=7$ に対応する振動モードも大きな応答（Fig.8）を示した。複数の要 因が重なる時, 外力振動数の近傍に固有振動数を有する振動モード も分数調波振動の不安定領域に関与するものと考えられる。すなわ ち, 外力加速度が増加して, 異なる振動モードによる不安定領域が

Table 3. Inner Products of Modes Amplitude of 1/2-Subharmonic Oscillation Components

\begin{tabular}{|c|cc|c|cc|}
\hline $\mathrm{H} ~ \mathrm{~mm}$ & 120 & 90 & 130 & 140 & 150 \\
$\mathrm{~Hz}$ & 364 & 410 & 360 & 356 & 350 \\
\hline$V_{360}^{130} \cdot V_{\mathrm{Hz}}^{\mathrm{WH}}$ & 0.985 & 0.967 & 1 & 0.774 & 0.730 \\
\hline
\end{tabular}
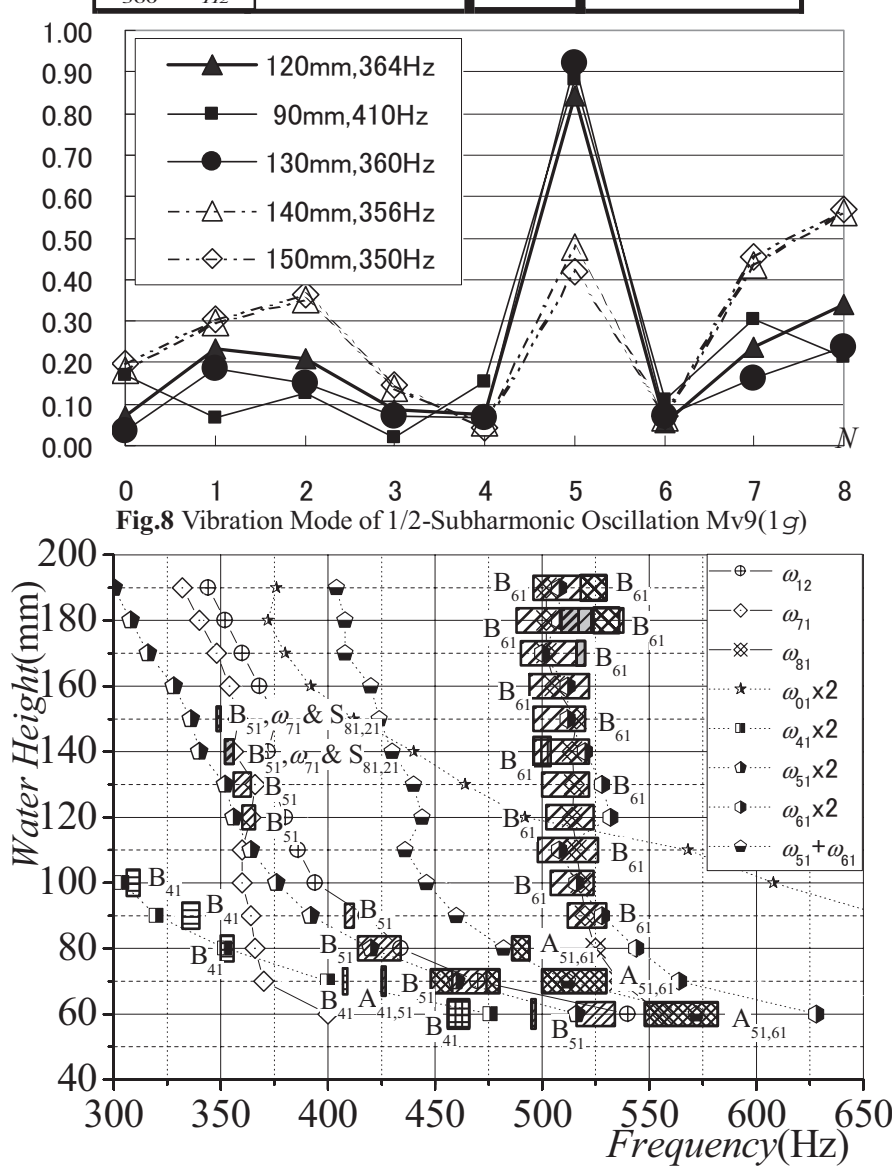

Fig.9 Instability Resion for Subharmonic Oscillation of Specimen Mv9(1g)
発生した後, この外力振動数の近傍に固有振動数を有する振動モー ドが不安定となり，この不安定領域の応答に混在する。このような 複数の要因が構成する不安定領域が発生する際, ある固有振動数近 傍に不安定領域が形成される例がこの $\mathrm{S}_{81,21}$ 型の不安定領域である。 (5) $1 / 3$ 倍分数調波振動

$1 / 3$ 倍分数調波振動のみが生起した応答は供試体 Mv 25 , 外力加速 度 $2 \mathrm{~g}$, 水高 $90 \mathrm{~mm}$, 外力振動数 $495 \mathrm{~Hz}$ 近傍 ${ }^{21)}\left(\mathrm{T}_{11}\right.$ に対応する）にの み観測された。周方向展開次数 $N=1$ の振動モードが最大の歪 $19 \mu$ 応答を示した。従来実験に用いた十数の供試体を含めても, $1 / 3$ 倍 分数調波振動応答のみが生起した応答はこれのみであり，同一のモ デルの加速度を $2.5 \mathrm{~g}$ としたケースでは $1 / 3$ 倍分数調波振動の不安定 領域は出現しなかった。これらから，1/3 倍分数調波振動のみが生起 する不安定領域は生起し難いものと思われる。すなわち，1/3 倍分数 調波振動は $1 / 2$ 倍分数調波振動の不安定領域の中で生起するようで ある。このため, $1 / 3$ 倍分数調波振動の不安定領域の発生は非線形性 が高く, 不安定領域と系の固有振動数に明確な関連を認め難い。

$1 / 3$ 倍分数調波振動の不安定領域の例を示す。供試体 Mv9, 外力振 動数 $2 \mathrm{~g}$, 水高 $190 \mathrm{~mm}$, 外力振動数 $332-340 \mathrm{~Hz}$ において, $\mathrm{T}_{41}(=342 \mathrm{~Hz})$ 近 傍で $1 / 3$ 倍分数調波振動成分, 主振動モード $N=4$ の歪振幅 $350 \mu$ が生 起した。この歪振幅は， 2 番目，および 3 番目に大きな歪振幅を持 つ振動モード $N=0$, および 5 のそれぞれ $86 \mu$ ，および $73 \mu$ と比較して 十分大きい。また，この不安定領域は $1 / 2$ 倍分数調波振動の不安定 領域 $\mathrm{A}_{01,51}(=338 \mathrm{~Hz})$ ともほぼ一致する。ゆえに, $\mathrm{A}_{01,51}$ 型の不安定領域 が $\mathrm{T}_{41}$ 型の不安定領域の発生に寄与していると判断される。ここで観 測された $1 / 3$ 倍分数調波振動の振幅は, $1 / 2$ 倍分数調波振動応答の主 振動モード $N=4$ の歪振幅は $84 \mu$ と比較しても, 大きな応答であった。

(6) 分数調波振動の不安定領域発生機構のまとめ

発生機構 (1) は他の発生機構と独立に $1 / 2$ 倍分数調波振動の不安定 領域を形成す。この不安定領域において, 外力加速度が増加すると, $1 / 3$ 倍分数調波振動が分岐することもある。

発生機構 (2) も独立に $1 / 2$ 倍分数調波振動の不安定領域を形成する ので, 発生し易い不安定領域となる。この不安定領域において，1/3 倍分数調波振動も随伴して生起することが多い。

発生機構 (3), (4), (5) は単独で生起することは珍しく, その他の発生 機構 (1), (2) の要因が重複して, $1 / 2$ 倍分数調波振動の不安定領域を形 成することが多いようだ。しかしながら、ある外力加速度の下で

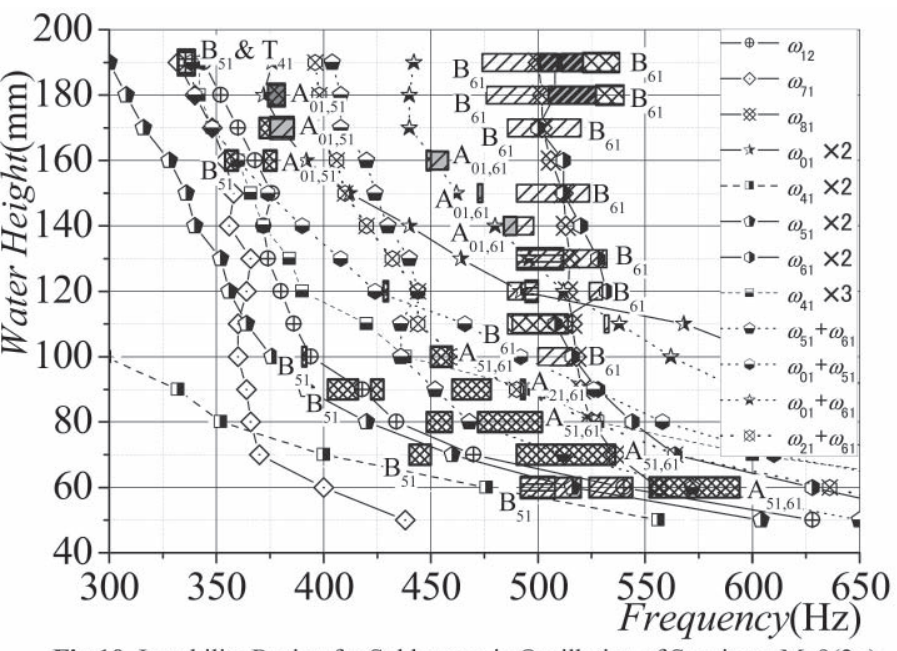

Fig.10 Instability Resion for Subharmonic Oscillation of Specimen Mv9(2g) 
発生した $1 / 2$ 倍分数調波振動の不安定領域近傍において，外力が増 加し， $1 / 3$ 倍分数調波振動応答が分岐する (2 次分岐) 現象は，高次 の非線形振動となり，発生の機構を予測することは困難である。

\section{5. 分数調波振動の不安定領域と発生機構}

供試体 Mv9，およびMv25を用いた実験から得られた水の入った 円筒タンクの応答実験から得られた分数調波振動が発生する不安定 領域を示し, 各不安定領域の発生機構を示し, 相互に比較して観察 される非線形振動の特異な性質を明らかにする。

\section{1 供試体 Mv 9}

供試体Mv9の外力加速度1gとしたケースの分数調波振動の不安定領 域をそれぞれFig.9に示す。図中の不安定領域に近接して発生機構を示 した。図中の記号はFig.7 と同一である。水高の変化に対応して, 固有 振動数 $\omega_{41}, \omega_{51}$, および $\omega_{61}$ は変化する。しかしながら, 外力振動数が これらの固有振動数の 2 倍近傍の多くの箇所において, 主振動モードが これらと同一の周方向展開次数を有する振動モードを持つ $1 / 2$ 倍分数調 波振動応答が分岐する。また, 外力振動数が二つ固有振動数 $\omega_{51}$ と $\omega_{61}$, および $\omega_{41}$ と $\omega_{51}$ の和近傍の時, これらに対応する振動モードが主要な 振動モードとなる $1 / 2$ 倍分数調波振動応答が分岐する。こ机ら不安定領 域の発生機構を記号 $\mathrm{A}_{51,61}$, および $\mathrm{A}_{41,51}$ と表示した。また, 4節の(3)に 示した $\mathrm{S}_{81,21}$ が関与する不安定領域の発生機構は $\mathrm{B}_{51}, \omega_{71}$, およ び $\mathrm{S}_{81,21}$ が関与すると判断して, 記号 $\mathrm{B}_{51}, \omega_{71} \& \mathrm{~S}_{81,21}$ と表示した。 供試体 Mv9 の外力加速度 $2 \mathrm{~g}$ としたケースの分数調波振動の 不安定領域, およびを発生機構を Fig. 10 に示す。図中の記号は

Table 4. Transition of Mode Amplitude of 1/2-Subharmonic Oscillation Components of Mv9

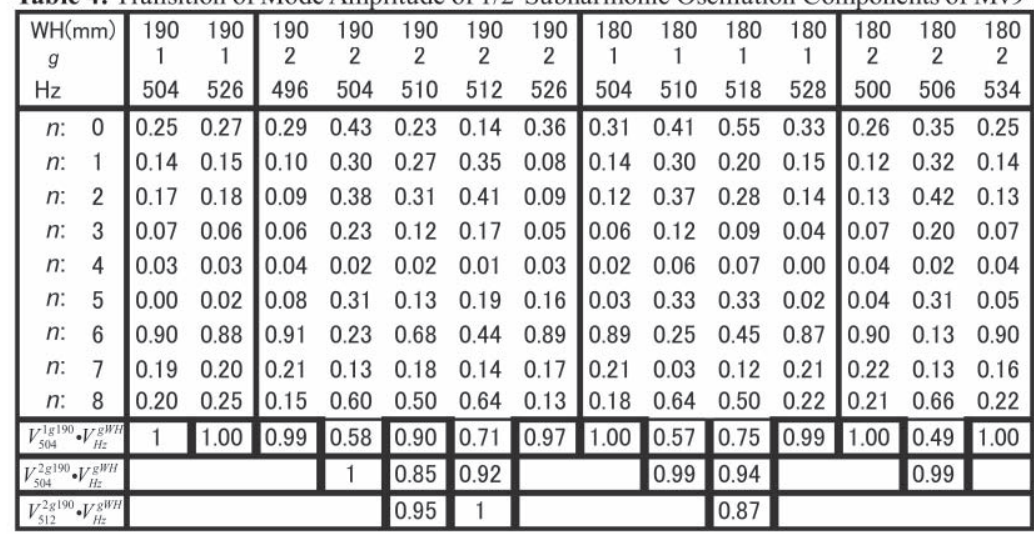

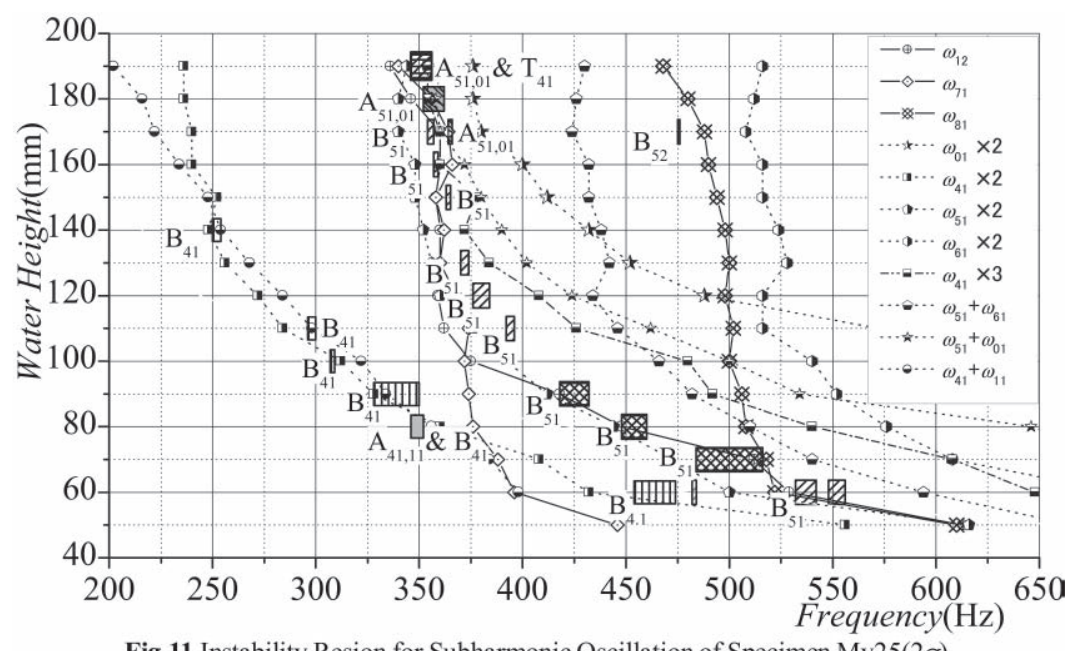

Fig.11 Instability Resion for Subharmonic Oscillation of Specimen Mv25(2g)
Fig.7 と同一である。ただし，外力加速度 $2 \mathrm{~g}$ の応答は水高が $150 \mathrm{~mm}$ 以下のケースに拈いて, 外力振動数が約 390-550 Hz の応 答のみが観測され, 外力加速度 $1 \mathrm{~g}$ の応答で観測された $\mathrm{B}_{41}$ の不 安定領域が応答曲線から脱落している。外力加速度が $1 \mathrm{~g}$ のと き発生せず, これが $2 g$ の時, 新たに観察された不安定領域を 示す。外力振動数が二つ固有振動数 $\omega_{01}$ と $\omega_{51}, \omega_{01}$ と $\omega_{61}$, ある いは $\omega_{21}$ と $\omega_{61}$ の和近傍の時, これらに対応する振動モードが主 要な振動モードとなる $1 / 2$ 倍分数調波振動応答が分岐する。こ れらの不安定領域に記号 $\mathrm{A}_{01,51}, \mathrm{~A}_{01,61}$ および $\mathrm{A}_{21,61}$ を付した。

水高 $190 \mathrm{~mm}$, および $180 \mathrm{~mm}$ の分数調波振動の不安定領域 $\mathrm{B}_{61}$ 型の中央部に周方向展開次数 $N=8$, および 0 が主振動モードと なる不安定領域が入り込んでいる。これらの不安定領域を構成 する振動モードを把握する目的で, これらの不安定領域から $1 / 2$ 分数調波振動応答の振動モードの振幅が最も大きくなる外力振 動数を採用し, 水高, 外力加速度, 外力振動数と各周方向展開 次数に対応する振動モード (3.2.1) を Table4 に示す。さらに, 3 種類の内積 (3.2.1) を算定して, 表の下段に示す。内積の算定時 の基準ベクトルは内積值 1 を記入した。

$V_{504}^{1 g 190}$ (添え字は外力加速度 $1 \mathrm{~g}$, 水高 $190 \mathrm{~mm}$, 外力振動数 $504 \mathrm{~Hz}$ を表す）基準ベクトル 1 とし，このベクトルと全ての振動モード の内積を算定し, 值が 0.97-1.00 となる振動モードは同じ振動モー ドであると判断できる。内積の值が 0.49-0.71 の振動モードは, $V_{504}^{2 g 190}$ (基準ベクトル 2）との内積を算定した。值が 0.99 のつの 振動モードは基準ベクトル 2 と同じモードと判断した。内積の值 が 0.85-0.94の振動モードは, $V_{512}^{2 g 190}$ (基準ベクトル 3) と内積を算定し, 内積值 $0.95,0.87$ を得た。これら 3 つの振動モードは相互に類似しているものの, 同一 の振動モードではないと判断した。

水高 $190 \mathrm{~mm}$, 外力加速度 $1 \mathrm{~g}$ の時, 不安定領域 $\mathrm{B}_{61}$ 型 は単独で生じ, 基準べクトル 1 の振動モードを有する $1 / 2$ 分数調波振動応答が観測された。外力加速度 $2 g$ の 時, 不安定領域 $\mathrm{B}_{61}$ 型の中に周方向展開次数 $N=8$ が主 振動モード（基準ベクトル 2) となる $1 / 2$ 分数調波振 動の高次の不安定領域が出現した。

水高 $180 \mathrm{~mm}$, 外力振動数 $1 \mathrm{~g}$ の時, 基準ベクトル 2 の主振動モードを持つ $1 / 2$ 分数調波振動応答が観測さ れた。この振動モードの応答は外力振動数が $2 g$ と増 加しても存在した。すなわち, 水高 $180 \mathrm{~mm}$, 外力振動 数 $1 \mathrm{~g}$ の時, 既に高次の不安定領域が発生していたこ とを意味する。

\section{2 供試体 Mv25}

供試体 Mv 25 , 外力加速度 $2 g$, 外力振動数 $200-650 \mathrm{~Hz}$ の下で観察された不安定領域と発生機構を Fig. 11 に示 す。記号はFig.7 と同一である。ただし, 新しい記号が ひとつ利用されている。図中の水高 $80 \mathrm{~mm}$, 外力振動 数 $350 \mathrm{~Hz}$ 近傍にある記号 $\square$ は, 周方向展開次数 $N=1$ が 主振動モードとなる $1 / 2$ 倍分数調波振動の不安定領域 を表す。これは固有振動数 $\omega_{41}(178 \mathrm{~Hz})$, および $\omega_{11}(176 \mathrm{~Hz})$ との和の外力振動数の下で稀に生起した $\mathrm{A}_{41,11}$ 型の $1 / 2$ 倍分数調波振動の不安定領域である。これら二つの固 
有振動数はこの水高では極めて隣接した值を有するので, $\mathrm{A}_{41,11}$ と $\mathrm{B}_{41}$ との両方が関与していると判断する。

この Fig.11 と供試体 Mv9（Fig.9,Fig.10）との不安定領域の類似性を概 説する。外力振動数が比較的低い不安定領域 $\mathrm{B}_{41}, \mathrm{~B}_{51}$, および $\mathrm{A}_{01,51}$ 等の不安定領域は, 上述した発生機構を利用して説明でき, 両者と も類似した不安定領域を形成する。水高 $190 \mathrm{~mm}$ の忘答において, 固 有振動数 $\omega_{41}$ の 3 倍の外力振動数近傍 $346-356 \mathrm{~Hz}$ の下で, $1 / 3$ 倍分数 調波振動の不安定領域が生起したのも, 両方の供試体に共通して いる。一方, 供試体 $\mathrm{Mv} 25$, 外力加速度 $2 g$ において, 固有振動数 $\omega_{61}$ が関与する $\mathrm{B}_{61}$ 型の不安定領域は発生せず, 供試体 Mv9 と大きな相 違を示した。

供試体 $\mathrm{Mv} 9$ 等において, 固有振動数 $\omega_{61}$ の 2 倍（振動数 $\mathrm{B}_{61}$ ） と固 有振動数 $\omega_{81}$ は類似した值をとる。 $\mathrm{B}_{61}$ 型の不安定領域が生起すると, 周方向展開次数 $N=8$, および $N=0$ の振動モードの振幅も大きい応答 を形成する。故に, 振動数 $\mathrm{B}_{61}$ と $\omega_{81}$ とが複合して, $1 / 2$ 倍分数調波振 動の不安定領域をつくる。しかしながら, 供試体 Mv25 等において, $\mathrm{B}_{61}$ 型の不安定領域は発生し難く, 複合した不安定領域も形成され なかった。この供試体において, 振動数 $\mathrm{B}_{61}$ と $\omega_{81}$ と值の相違が大き いことも要因のひとつであろう。

\section{6. 結語}

本論文で報告している実験的研究から，周期的な水平外力を受ける 水の入った円筒タンクに次のような非線形振動応答, および分数調波 振動の不安定領域の出現が観測される。

1）水の入った円筒タンクが周期的な水平外力を受けた時，高調波振動 や分数調波振動を伴う非線形振動応答が生起する。このうち, 分数 調波振動応答は定常的な応答曲線から分岐する振動として出現し, 応答曲線上に不安定領域を形成し，かつ振幅の大きな応答を示す。

2) この系の定常応答に $1 / 2$ 倍分数調波振動応答が初めて生起する不安 定領域と主振動モードの関係, 寸なわち定常応答曲線から分数調波 振動が発生する機構は, 系のバルジング固有振動数と対応する固有 振動モードから予測することが可能である。外力がある程度の大き さを持ち, 外力振動数が系のバルジング固有振動数と (10), (11), (12) 式の関連を有する近傍に在る時, それぞれに対応する分数調波振動 が生起し得る。外力振動数が, 複数の固有振動数が関係する (12), あ るいは(13) 式を満たす近傍に生起する不安定領域は比較的発生し難 いようである。これらの発生機構は, 実験時に観測されたほぼ全て の $1 / 2$ 倍分数調波振動応答の不安定領域の発生を説明できる。

3） $1 / 2$ 倍分数調波振動の不安定領域において, この忘答が大きくなる と, 別の振動モードを有する分数調波振動が生起する高次の不安定 領域が出現する可能性がある。多くの $1 / 3$ 倍分数調波振動はこのよう な発生機構を有するものと考えられる。また, この分数調波振動の 高次不安定領域の発生に, 外力振動数が (13) 式を満たす振動モード, およびこの振動数近傍に固有振動数を有する振動モードが関与する と予測される。しかし, 高次不安定領域の発生は非線形性が高く, 発生機構を正確に予測することは現時点では困難である。

4) 分数調波振動の不安定領域の発生を正確に予測するためには, 系 の減衰の影響を含め, 分数調波振動の不安定領域の定量的な検討を 遂行する必要があり, 今後の課題である。

\section{謝辞}

本研究は科学研究費補助金（基盤研究 (C) (2), 課題番号 16560506）他の援助を受けました。この研究の実験を遂行し, 粘り強く実験データの整理に尽力した大学院学生嶋本耕三君, 岩下一徹君, および中村達哉技術職員に感謝します。これは 1985 年以来の研究の積み重㸚の成果です。この実験に携わった 数多くの学生の献身的な努力に禹心から感謝します。

\section{参考文献}

1)Luke,J.C.:A variational principle for a fluid with a free surface,J. Fluid Mech,vol.27, part.2,pp.395-397,1967

2)Clough,R.W.,Niwa,A. et al.:Experimental Seismic Study of Cylindrical Tanks, Proc.ASCE,vol.105,no.ST12, pp.2565-2597,1979

3) Haroun,M.A. et al.:Dynamic Characteristics of Liquid Storage Tanks: Complications in Free Vibration Analysis of Tanks,Proc.ASCE，Vol.108,No.EM5, pp.783-818,1982

4) 皆川洋一: 液体の入った円筒シェルの非線形振動解析, 日本建築学会大会 学術講演梗概集,pp.2565-2566, 1984. 10

5) 皆川洋一: 有限変形場でのポテンシャル流体と弾性体容器の相互作用を 支配する汎関数，日本建築学会構造系論文報告集，第 362 号,pp.105-115, 1986. 4

6) 大森博司、松井徹哉、日比野浩: 液体貯槽の有限振幅液面動摇に関する 研究、日本建築学会構造系論文報告集, 第 375 号. 5,pp.65-72,1987

7) 皆川洋一: 円筒シェルの水平振動実験における高次振動モードおよび非 線形振動の生起, 日本建築学会大会学術講演梗概集, B - 1, p p . 1233 1234,1990. 10

8) Y.Minakawa, Nonlinear Oscillation Analyses of Interactive Behaviors between the Potential Fluid and Tanks of Shell of Revolution in Finite Deformations, 日本建築学 会構造系論文報告集, No.435,1992

9) 末広康之, 皆川洋一: 水の入った円筒シェルの水平振動実験、日本建築学 会大会学術講演梗概集,B-1,pp.553-554,1995.10

10) 野間紀男, 上薗忠敬, 皆川洋一: 水の入った円筒シェル容器の水平振動実 験における非線形振動応答, 日本建築学会九州支部研究報告, 第 38 号 · 1,pp.273-276,1999. 3

11) 野間紀雄,皆川洋一:水平方向周期外力を受ける水の入った円筒タンクの振 動実験, 自動測定システムを用いた振動実験における円筒タンクに生起す る非線形振動応答, 日本建築学会九州支部研究報告, 第 39 号・1,pp.309312,2000

12)皆川洋一:水の入った円筒タンクに生起する非線形振動応答, NONLINEAR OSCILLATION RESPONSE OF A CYLINDRICAL TANK WITH WATER, 日本建 築学会構造系論文集,No.531, pp.125-132, 2000. 5

13) 皆川洋一, 中村達哉: 水の入った円筒シェルの水平振動実験、新測定シス テムの概要、日本建築学:会学術講演梗概集、B-1,pp.755-756,2003

14) 中村達哉, 皆川洋一: 水の入った円筒シェルの水平振動実験、共振曲線、日 本建築学会学術講演梗概集、B-1,pp.757-758,2003

15) 嶋本耕三, 中村達哉、皆川洋一: 水の入った円筒シェルの水平振動実験、 日本建築学会九州支部研究報告, 第 43-1,169-172,2004

16) 中村達哉, 嶋本耕三, 皆川洋一: 水の入った円筒タンクの水平振動実験 水高の変化がタンク周方向ひずみ応答に及ぼす影響 -, 日本建築学会学術 講演梗概集、B-1,782-783,2004

17) 嶋本耕三, 皆川洋一: 水の入った円筒タンクの水平振動実験, 日本建築 学会九州支部研究報告, 第 44 号 1,pp.561-564,2005.3

18) 中村達哉, 皆川洋一: 水の入った円筒タンクの水平振動実験における動 的不安定領域, 日本建築学会学術講演梗概集, 構造 I,pp.829-830,2005

19) 下高原理, 皆川洋一: 水の入った円筒タンクの水平振動実験, 日本建築学 会九州支部研究報告, 第 45 号 1,pp.209-212, 2006. 3

20) 岩下一徹, 皆川洋一, 山本憲司, 中村達哉: 水の入った円筒タンクの非線 形振動応答に関する実験的研究, 日本建築学会九州支部研究報告, 第 46 号 1, pp.549-552,2007.3

21) 皆川洋一: 水平地動を受ける水の入った円筒タンクにおける非線形振動 応答の研究, 平成 16-18 年度科学研究費補助金（基盤研究 (C) (2)) 研究 成果報告書（課題番号 $16560506 ）$

（2009年 1 月 9 日原稿受理，2009年 4 月16日採用決定） 